\title{
Non-operative management of perforated peptic ulcer: A single-center experience
}

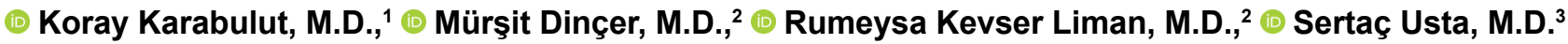

${ }^{1}$ Department of General Surgery, Memorial Sisli Hospital, İstanbul-Turkey

${ }^{2}$ Department of General Surgery, Fırat University Faculty of Medicine, Elazı̆̆-Turkey

${ }^{3}$ Department of General Surgery, İnönü University Faculty of Medicine, Malatya-Turkey

\begin{abstract}
BACKGROUND: Perforation is a rare complication of peptic ulcer. Although the most widely accepted treatment for peptic ulcer perforation is surgery, non-operative treatment can be an option in selected patients. In this study, we aimed to present our non-surgical treatment experience in peptic ulcer perforation.

METHODS: In this study, the data of the patients who were treated due to peptic ulcer perforation between January 2012 and September 2017 in our clinic were retrospectively reviewed. The diagnosis was reached by physical examination and radiologic findings. After obtaining the informed consent from the patients, non-operative treatment was performed to the selected patients who had normal vital parameters and did not have findings of generalized peritonitis in the abdominal examination. Oral food and fluid intake were stopped and intravenous fluid, antibiotics and pantoprazole were administered to all patients in this study.

RESULTS: A total of $4 \mathrm{I}$ patients were treated due to the diagnosis of peptic ulcer perforation in our clinic during the study period. Out of $4 \mathrm{I}$ patients, while 35 of the patients were operated, six of them were treated non-operatively. There were peritoneal irritation signs and symptoms in the upper quadrants on physical examination in all of the patients. None of them had generalized peritonitis. Abdominal X-ray and computed tomography were obtained from all of the patients. None of the patients in the non-operative group underwent any interventional procedure or surgery during the follow-up period. The median length of hospital stay was four days in this group. All of the patients were discharged uneventfully.
\end{abstract}

CONCLUSION: Standard treatment of peptic ulcer perforation in most of the patients is still surgical repair. Non-surgical treatment should be kept in mind as an option in the selected patients who had normal vital parameters and did not have any findings of generalized peritonitis in the abdominal examination. In this way, it may be possible to avoid unnecessary surgery and reduce the possible morbidity and mortality associated with the operation.

Keywords: Conservative treatment; non-operative treatment; peptic ulcer perforation.

\section{INTRODUCTION}

Perforation is a rare complication of peptic ulcer. The most widely accepted treatment method for peptic ulcer perforation is surgery. ${ }^{[1]}$ In a few studies in the literature, conservative treatment is also recommended in highly selected patients. In the present study, we aimed to present our nonsurgical treatment experience in the peptic ulcer perforation.

\section{MATERIALS AND METHODS}

In this study, the data of the patients who were treated by hospitalizing in our clinic due to the diagnosis of peptic ulcer perforation between January 2012 and September 2017 were reviewed from the hospital database. The diagnosis was made by detecting intraperitoneal free air using direct abdominal X-ray and abdominal computed tomography in the patients with sudden onset of abdominal pain with accompanying signs

Cite this article as: Karabulut K, Dinçer M, Liman RK, Usta S. Non-operative management of perforated peptic ulcer: A single-center experience. Ulus Travma Acil Cerrahi Derg 2019;25:585-588.

Address for correspondence: Koray Karabulut, M.D.

Memorial Şişli Hastanesi, Genel Cerrahi Kliniği, Şişli, 34385 i̇stanbul, Turkey

Tel: +90 212 - 3146666 E-mail: koraykarabulut@yahoo.com

Ulus Travma Acil Cerrahi Derg 2019;25(6):585-588 DOI: 10.14744/tjtes.2019.31967 Submitted: 08.01.2019 Accepted: 15.01.2019 Online: 25.10.2019

Copyright 2019 Turkish Association of Trauma and Emergency Surgery 


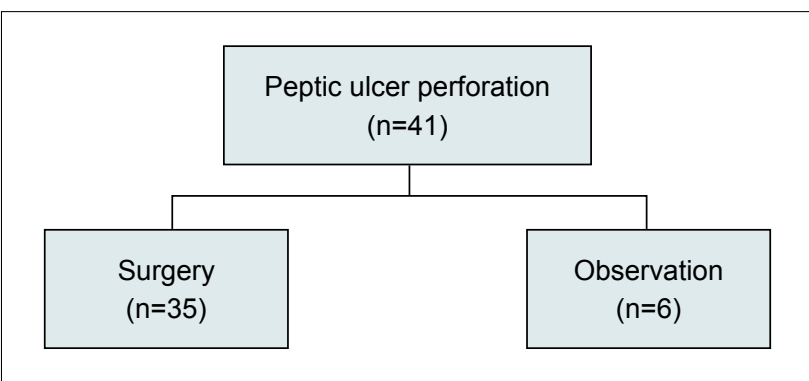

Figure 1. Patients, according to the treatment arms.

and symptoms of peritoneal irritation on physical examination consistent with peptic ulcer perforation. Non-operative treatment was administered to the selected patients who had normal vital parameters and did not have findings of generalized peritonitis in the abdominal examination. The informed consent was obtained from each patient who participated in this study.

\section{RESULTS}

A total of 41 patients were treated due to the diagnosis of peptic ulcer perforation in our clinic between January 2012 and September 2017. Out of 41 patients, while 35 (85\%) of the patients were treated with laparoscopic or open surgery, six $(15 \%)$ of the patients were treated non-operatively (Fig. I). Five of the patients were male, and one patient was female. The ages of these patients ranged from 18 to 85 years. The American Society of Anesthesiologists score (ASA) was I in four of the patients, II in one of the patients, and III in one patient of the patients. The demographic and clinical parameters of the patients are given in Table I.

On physical examination, there was tenderness in the epigastric area in all of the patients. None of them had any signs of generalized peritonitis. All of them were hemodynamically stable. Tachycardia or hypotension was not observed in any of the patients. There was free air under the diaphragm in the direct abdominal X-ray in five of the patients. In one patient, although it can not be seen in the abdominal X-ray, there was free air around the duodenum and falciform ligament in

Table I. The demographic and clinical parameters of the patients

\begin{tabular}{lccccc}
\hline $\begin{array}{l}\text { Patient } \\
\text { no }\end{array}$ & Age & Gender & $\begin{array}{c}\text { ASA } \\
\text { Score }\end{array}$ & WBC & $\begin{array}{c}\text { Hospital } \\
\text { stay (day) }\end{array}$ \\
\hline I & 18 & Male & I & 17430 & 5 \\
2 & 22 & Male & I & 13690 & 4 \\
3 & 29 & Male & I & 8580 & 4 \\
4 & 52 & Female & I & 7490 & 4 \\
5 & 63 & Male & II & 13900 & 3 \\
6 & 85 & Male & III & 17350 & 4 \\
\hline
\end{tabular}

ASA: American Society of Anesthesiologists score; WBC: White Blood Cell. abdominal computed tomography. Intravenous contrast-enhanced abdominal tomography was obtained for all of the conservatively followed patients. Although intraperitoneal free air was present in all of the patients, perihepatic fluid was present in only three of them. Abdominal X-ray and computed tomography images of patients can be seen in Figures 2a, b, 3a, b, 4a, b.

Oral food and fluid intake were stopped in all of the patients, intravenous fluid, antibiotics (ceftriaxone and metronidazole) and pantoprazole administered to all patients. None of the patients had nausea and vomiting. Nasogastric decompression was not used in any of the patients. They were followed up by serial physical examination. None of the patients underwent an interventional procedure or surgery during the follow-up period. All of the patients were discharged uneventfully. The median length of hospital stay was four days (3-5). Helicobac-
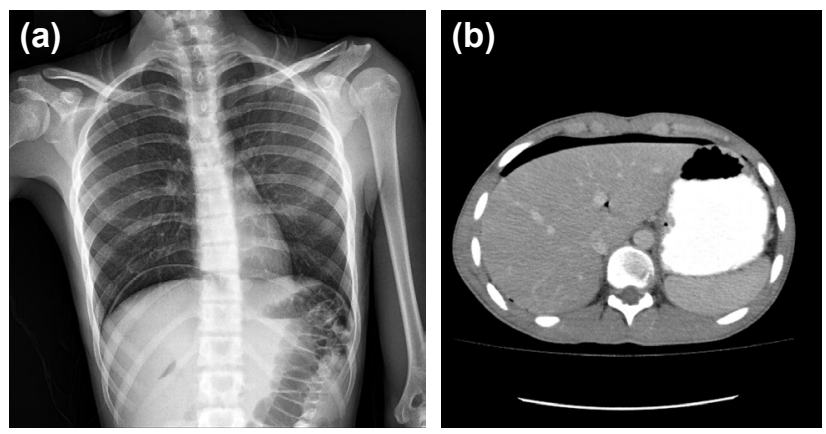

Figure 2. (a, b) Abdominal X-ray and CT, showing subdiaphragmatic air.
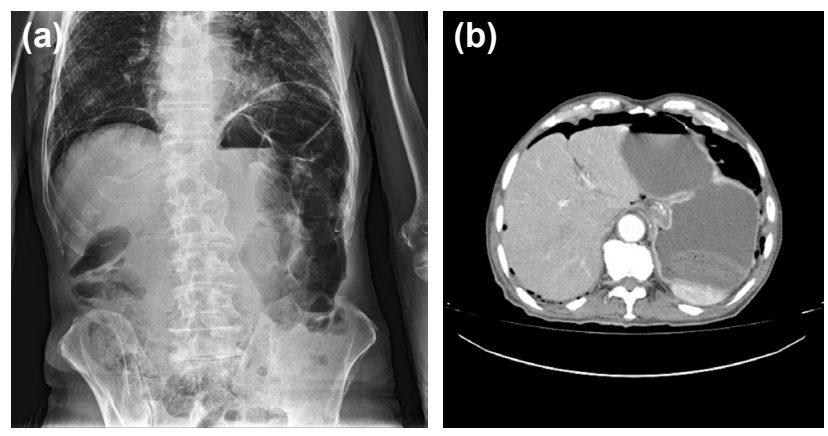

Figure 3. (a, b) Abdominal X-ray and CT, showing subdiaphragmatic air.
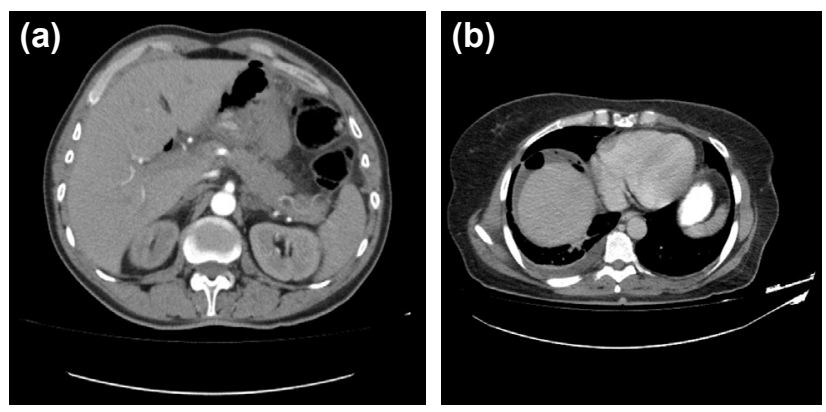

Figure 4. (a) CT showing subdiaphragmatic and subhepatic air. (b) CT showing perihepatic fluid an air. 
ter pylori eradication treatment was prescribed and a control gastroscopy appointment was scheduled for six weeks later.

\section{DISCUSSION}

Many factors, such as $\mathrm{H}$. pylori, non-steroidal anti-inflammatory drugs, corticosteroids, bisphosphonates, smoking, alcohol and stress, are effective in the pathogenesis of peptic ulcer disease. ${ }^{[2]}$ Duodenal or gastric perforation due to peptic ulcer disease, which is seen less frequently with the use of proton pump inhibitors, is still a reason for surgical emergencies. ${ }^{[3,4]}$ Perforations are more commonly seen in duodenal ulcers compared with gastric ulcers. ${ }^{[l]}$ Duodenal ulcer perforations are frequently seen on the anterior surface of the duodenal bulb. Mortality rates are higher in gastric perforations than in duodenal perforations. ${ }^{[5]}$ Treatment of the patients who are hemodynamically unstable and have signs of generalized peritonitis is surgical. Surgery can be performed either open or laparoscopic. During the surgery, most surgeons observe that the perforation sites are closed by the omentum, liver, or adjacent tissues. Surgeons usually remove these tissues and attachments to see the perforation area. From this point of view, the necessity of surgery has been questioned, and in some selected patient groups, these patients could be treated conservatively without any need for surgery.

A case of peptic ulcer perforation treated without surgical intervention was first presented by Redwood in 1870. ${ }^{\left[{ }^{[}\right]}$Wangensteen first proposed the conservative approach to peptic ulcer perforation in 1935. Taylor described broad-spectrum antibiotic therapy, intravenous fluid replacement, and Helicobacter Pylori eradication therapies as a conservative approach in peptic ulcer perforations in 1946. ${ }^{[6,7]}$

In the literature, it is stated that the patients who are under 70 years of age, who are admitted to hospital within 24 hours after the onset of the symptoms, who have localized peritonitis findings and non-extensive fluid in the abdomen by imaging methods and whose peritoneal irritation symptoms are limited in the upper quadrants, can be followed-up conservatively. ${ }^{[8,9]}$ The success rate of the conservative approach using this method was reported as $72 \%$ by Crofts et al. ${ }^{[8]}$ In our study, all of the patients were admitted to the hospital at an early stage. Five cases were under 70 years of age. One case was 85 years old. Peritoneal irritation findings were localized in the epigastric region and in the right upper quadrant. Free air was detected in radiological imaging. The amount of fluid was few and limited in cases with free fluid in the abdomen. They did not require an interventional procedure.

Surgical treatment is recommended for the conservatively followed patients if no clinical and imaging findings are improved within 24 hours. ${ }^{[3,10,11]}$ In a study conducted on the 132 conservatively followed cases by Cao et al.,. ${ }^{[3]}$ it was reported that 25 patients without clinical improvement were undergone to surgery after 12 hours follow-up. In our se- ries, no clinical worsening was observed in the conservatively followed cases. Neither surgical nor radiologic interventions were required; vital signs were stable, and physical examination findings became better during the follow-up period.

In a retrospective study conducted by Devitt et al. ${ }^{[12]}$ in 1967, the findings showed that the mortality rates were $72.5 \%$ in patients who did not undergo surgery and $7.5 \%$ in patients who underwent surgery. In 197I, Cohen et al. ${ }^{[13]}$ reported these rates as $100 \%$ and $9 \%$. With the increase in the use of antacid treatments, this ratio lowered. ${ }^{[14]}$ In our study, although the number of patients followed was limited, there was no mortality in the patients who were followed-up conservatively or underwent surgery.

There are publications about the conservative follow-up with nasogastric drainage in peptic ulcer perforation. ${ }^{[15,16]}$ In our cases, the nasogastric catheter was not inserted to the patients, so patient comfort increased, unlike non-surgical methods described in the literature. In the studies, it was reported that the length of hospital stay was longer in the conservatively followed patients compared with the patients who underwent surgery. ${ }^{[1]}$ In our study, the length of hospital stay was similar to the patients who underwent surgery. In our study, another aspect differing from the literature was that the conservatively followed patients had low and medium ASA scores. While the conservative approach was generally tried in patients with high surgical risk in the literature, most of the cases in our study were followed-up with the ASA I-II score. The indication for conservative follow-up was completely based on clinical findings and physical examination in our series.

\section{Conclusion}

Standard treatment of peptic ulcer perforation in most of the patients is still surgical repair. Non-surgical treatment should be considered as an option in the selected patients who had normal vital parameters and did not have findings of generalized peritonitis in the abdominal examination. In this way, it may be possible to avoid unnecessary surgery and reduce the possible morbidity and mortality associated with the operation.

\section{Conflict of interest: None declared.}

\section{REFERENCES}

1. Vijayakumar A, Mallikarjuna MN, Vijayraj P, Ajitha Naika, Shivaswamy BS. Non operative management of perforated peptic ulcer an algorithm approach. Int J Biomed Adv Res 2013;4:67-72. [CrossRef]

2. Søreide K, Thorsen K, Harrison EM, Bingener J, Møller MH, OheneYeboah M, et al. Perforated peptic ulcer. Lancet 2015;386:1288-98.

3. Cao F, Li J, Li A, Fang Y, Wang YJ, Li F. Nonoperative management for perforated peptic ulcer: who can benefit? Asian J Surg 2014;37:148-53.

4. Thorsen K, Søreide JA, Søreide K. Scoring systems for outcome prediction in patients with perforated peptic ulcer. Scand J Trauma Resusc Emerg Med 2013;21:25. [CrossRef] 
5. Svanes C, Lie RT, Svanes K, Lie SA, Søreide O. Adverse effects of delayed treatment for perforated peptic ulcer. Ann Surg 1994;220:168-75.

6. Bertleff MJ, Lange JF. Perforated Peptic Ulcer Disease: A Review of His tory and Treatment. Dig Surg 2010;27:161-69. [CrossRef]

7. Hanumanthappa MB, Gopinathan S, Guruprasad RD, Dsouza N. A non-operative treatment of perforated peptic ulcer: a prospective study with 50 cases. J Clin Diagn Res 2012;6:696-99.

8. Crofts TJ, Park KG, Steele RJ, Chung SS, Li AK. A randomized trial of nonoperative treatment for perforated peptic ulcer. N Engl J Med 1989;320:970-3. [CrossRef]

9. Tanaka R, Kosugi SI, Sakamoto K, Yajima K, Ishikawa T, Kanada T, et al. Treatment for perforated gastric ulcer: a multi-institutional retrospective review. J Gastrointest Surg 2013;17:2074-81. [CrossRef]

10. Satoh K, Yoshino J, Akamatsu T, Itoh T, Kato M, Kamada T, et al. Evidence-based clinical practice guidelines for peptic ulcer disease 2015. J Gastroenterol 2016;51:177-94. [CrossRef]
11. Lay PL, Huang HH, Chang WK, Hsieh TY, Huang TY, Lin HH. et al. Outcome of nonsurgical intervention in patients with perforated peptic ulcers. Am J Emerg Med 2016;34:1556-60. [CrossRef]

12. Devitt JE, Taylor GA. Perforated peptic ulcer. Can Med Assoc J 1967;96:519-23.

13. Cohen MM. Treatment and mortality of perforated peptic ulcer: a survey of 852 cases. Can Med Assoc J 1971;105:263-9.

14. Bucher P, OulhaciW, Morel P, Ris F, Huber O. Results of conservative treatment for perforated gastroduodenal ulcers in patients not eligible for surgical repair. Swiss Med Wkly 2007;137:337-40.

15. Saber A, Gad MA, Ellabban GM. Perforated duodenal ulcer in high risk patients: is percutaneous drainage justified? North Am J Med Sci 2012;4:35-9. [CrossRef]

16. Mouly C, Chati R, Scotté M, Regimbeaua JM. Therapeutic management of perforated gastro-duodenal ulcer: Literature review. J Visc Surg 2013;150:333-40. [CrossRef]

\section{ORİIINAL ÇALIŞMA - ÖZET}

\section{Peptik ülser perforasyonunun ameliyatsız tedavisi: Tek merkez deneyimi Dr. Koray Karabulut, ${ }^{1}$ Dr. Mürşit Dinçer, ${ }^{2}$ Dr. Rumeysa Kevser Liman,, ${ }^{2}$ Dr. Sertaç Usta ${ }^{3}$}

${ }^{1}$ Memorial Şişli Hastanesi, Genel Cerrahi Kliniği, İstanbul

${ }^{2}$ Fırat Üniversitesi Tıp Fakültesi, Genel Cerrahi Anabilim Dalı, Elazığ

3̇nönü Üniversitesi Tıp Fakültesi, Genel Cerrahi Anabilim Dalı, Malatya

AMAÇ: Perforasyon, peptik ülserin nadir bir komplikasyonudur. Peptik ülser perforasyonunun yaygın kabul gören tedavisi cerrahi olmakla birlikte, ameliyatsız tedavi seçilmiş hastalarda bir seçenek olabilir. Bu çalışmada, peptik ülser perforasyonunda ameliyatsız tedavi tecrübemizi paylaşmayı amaçladık.

GEREÇ VE YÖNTEM: Ocak 2012 ile Eylül 2017 tarihleri arasında peptik ülser perforasyonu tanısıyla kliniğimizde tedavi edilen hastalara ait veriler geriye dönük olarak değerlendirildi. Tanı, fizik muayene ve radyoloji bulguları ile kondu. Ameliyatsız tedavi, vital parametreleri normal olup, fizik muayenede yaygın peritonit bulguları olmayan seçilmiş hastalara aydınlatılmış onamdan sonra uygulandı. Hastaların tamamında ağızdan gıda ve sıvı alımı durduruldu, intravenöz sıvı, antibiyotik ve pantoprazol başlandı.

BULGULAR: Çalışma süresince 4 I hasta kliniğimize peptik ülser perforasyonu tanısı ile yatırılarak tedavi edildi. Bu hastaların $35^{\prime} i$ ameliyat edilirken altısı konservatif olarak takip edildi. Hastaların tamamında, fizik muayenede karın üst kadranlarda periton irritasyon semptom ve bulguları vardı. Hiçbirinde yaygın peritonit mevcut değildi. Hastaların tamamına direkt karın grafisi ve tomografi çekildi. Ameliyatsız tedavi grubundaki hastaların hiçbirine takip süresince cerrahi veya girişimsel radyolojik bir işlem yapma gerekliliği oluşmadı. Bu gruptaki hastalarda ortanca hastanede kalış süresi dört gündü. Hastaların tamamı sorunsuz olarak taburcu edildi.

TARTIŞMA: Peptik ülser perforasyonlu hastaların çoğunda standart tedavi halen cerrahidir. Ameliyatsız tedavi, vital parametreleri normal olan ve karın muayenesinde yaygın peritonit bulguları olmayan seçilmiş hastalarda bir tedavi seçeceği olarak akılda bulundurulmalıdır. Bu şekilde, gereksiz yere cerrahi yapmaktan ve cerrahinin olası morbidite ve mortalitesinden kaçınmak mümkün olabilir.

Anahtar sözcükler: Ameliyatsız tedavi; konservatif tedavi; peptik ülser perforasyonu.

Ulus Travma Acil Cerrahi Derg 2019;25(6):585-588 doi: 10.14744/tjtes.2019.31967 